\title{
Clinical manifestations of Hepatitis B: its association with serum profile of cytokine genetic polymorphism
}

\author{
Manifestações clínicas da Hepatite B: sua associação com perfil sérico de \\ polimorfismo genético de citocinas
}

Maurício de Souza Campos ${ }^{1}$, Maria Isabel Schinonni², Songeli Menezes Freire ${ }^{3}$

\author{
${ }^{1}$ Biólogo. Mestrando do Programa de Pós-graduação \\ Processos Interativos dos Órgãos e Sistemas, ICS - UFBA \\ ${ }^{2}$ Professora Adjunto. Departamento de Biofunção. Programa de \\ Pós-Graduação Processos Interativos dos Órgãos e Sistemas, ICS - UFBA \\ ${ }^{3}$ Professora Adjunto. Departamento de Biointeração. Programa de \\ Pós-Graduação Processos Interativos dos Órgãos e Sistemas, ICS - UFBA
}

\begin{abstract}
Objective: This systematic review aims to review the correlation among the genetic polymorphism of cytokine, production and clinical presentation of these serum proteins in forty seven (47)hepatitis B chronic. Methodology: For this we conducted a systematic review of articles obtained by searching the databases Journals Portal CAPES and Pub Med The papers selected were published between the years 200 and 2013. We used the following descriptors: 1. Chronic hepatitis B, 2. Cytokine gene polymorphism 3. Anti-hepatitis $B$ / genetics, 4. Hepatitis B virus / genetics. Results: the articles found in the search, twenty five (25), which were used in this review. Conclusions: The research on the correlation between the genetic polymorphism of cytokine production of these serum and clinical presentation of chronic hepatitis $B$ is still incipient, although this may elucidate the immunological mechanisms responsible for viral clearance and the chronicity of the infection.

Keywords: Chronic Hepatitis B. Genetic Polymorphism of Cytokines. Antibodies. Hepatitis B.
\end{abstract}

\begin{abstract}
Resumo
Objetivo: Essa revisão sistemática teve como objetivo revisar a correlação entre o polimorfismo genético das citocinas com a produção sérica dessas e a apresentação clínica da Hepatite B crônica. Metodologia: Foi realizada uma atualização do estado da arte com artigos obtidos por meio de busca nos bancos de dados do Portal de Periódicos da CAPES e PubMed. Os artigos científicos selecionados foram publicados entre os anos de 2000 e 2013. Foram utilizados os seguintes descritores: 1. Hepatite B crônica, 2. Polimorfismo genético de citocinas; 3.Anticorpos anti-hepatite B/genética, 4. Vírus da Hepatite B/genética. Resultados: Dos artigos encontrados na busca, foram selecionados vinte e cinco (25), os quais foram usados nessa revisão. Conclusão: A pesquisa acerca da correlação entre o polimorfismo genético das citocinas com a produção sérica dessas e a apresentação clínica da Hepatite B crônica ainda é insipiente, embora isso possa elucidar os mecanismos imunológicos responsáveis pela eliminação viral e pela cronificação da infecção. Palavras-chave: Hepatite B Crônica. Polimorfismo Genético de Citocinas. Anticorpos. Hepatite B.
\end{abstract}

\section{INTRODUCTION}

Infection with the hepatitis B virus can produce diversely extreme clinical cases, ranging from asymptomatic infection to hepatocellular carcinoma. The vast majority of adult individuals infected - average of $90 \%$ - develop the asymptomatic form. Others may develop severe forms of the disease that can lead to cirrhosis and hepatocellular carcinoma (BAUMERT et al., 2007). Another possibility, although the chances are relatively small, is the development of the fulminant form of the disease, especially in cases of co-infection with hepatitis delta virus. The latency period of HBV infection usually varies from four to twelve

Correspondência / Correspondence: Maurício de Souza Campos. Instituto de Ciências da Saúde, Universidade Federal da Bahia. Avenida Reitor Miguel Calmon, S/N. Vale do Canela. Sala 400. Salvador-BA, Brasil. Telefone: +55 713283.8959 weeks. In the acute phase, HBs antigen (HBsAg) is easily detected in the serum of individuals, and subsequently followed by the appearance of Immunoglobulin (IgM) an$\mathrm{ti}-\mathrm{HBC}$ and anti-HBC. Another significant factor is the $\mathrm{HBe}$ antigen (HBeAg) which detection in serum of infected individuals suggests the occurrence of viral replication and infectivity. This is a remark of the symptomatic stage of the disease, detectable at the end of the incubation period and that disappears shortly before the HBsAg. It is usually associated with the presence of the viral genome. Convalescence occurs two to sixteen weeks after the infection, with a declining of IgM anti - $H B C$, persistent of IgG anti $H B c$ and disappearance of $H B S A g$. The resolving is characterized by HBsAg's seroconversion to anti - HBs, which confers immunity to the individual and the normalization of liver enzymes. 
The World Health Organization refers to approximately two billion people infected worldwide, where 360 million are chronic carriers (SBI, 2006; MAST et al, 2006; $W H O, 2007)$. The evolution of the disease to liver failure and/or hepatocellular carcinoma (HCC) responds worldwide for 500.000 to one million deaths per year and stands for the major cause of liver transplantation (LOK; McMAHON, 2007). So far, eight genotypes are described and identified by the letters $A$ to $H$, being the subtypes $A$ and $F$ the most prevalent in Brazil (TONETTO, 2009; PARANÁ et al., 2005; ALMEIDA, 2009). The infection of hepatocytes by hepatitis $B$ virus confers a response from Th1, with effective NK and LT cell's activity. IFN - $\gamma$ is one of the most important mediators of the immune response to $\mathrm{HBV}$, and along with other inflammatory cytokines acts on the control of viral replication.

Studies have revealed a lack of pattern in the occurrence of hepatitis $B$ worldwide. This observation led researchers to develop hypotheses about the influence of genetic factors on the course of infection. Among the different ethnic groups affected, there could be genetic factors that lead to higher or lower susceptibility to infection and progression to chronicity or resolution. Signh et al. (2007) investigated the correlation among different populations of Human Leucocitary Antigen (HLA) Hepatitis B and found that HLA DR13 is consistently associated with the bleaching time of infection to the alleles HLADRB1 * 11 / 12 , and DQB1 * 0301, strongly associated with HBV permanence.

The Asian continent has been making significant efforts, sustained by the amount of studies published in scientific journals, in attempt to evaluate the connexion between serum and cytokine gene polymorphisms and the clinical manifestations of hepatitis B (CHEONG et al, 2006; KIKl et al. 2006).

The prevalence of infection with hepatitis $B$ virus also appears quite heterogeneously in Brazil, being the Northern region the most affected area and the Southern states registering the lowest levels. Studies have placed the Amazon as an endemic area of high number of cases, predominantly found on the western side. The literature also identifies the cities of Cascavel (PR), Chapecó (SC) and Francisco Beltrão (PR), all located in the South, and the municipalities of Karai (MG) and Cachoeira do Itapemirim (ES), in the Southeast, as foci of high endemicity of HBV infection in Brazil (SOUTO, 1999).

The Department of Health Surveillance (SVS) of the Ministry of Health (MOH), reported that in 20076.14 / 100,000 new cases of hepatitis B were notified (BRAZIL, 2009) with greater occurrence rates in the South $(12,89 / 100,000)$ and lowest in the Northeast. Comparative studies of epidemiological bulletins from the Ministry of Health from 1999 to modern times show an increase in the incidence of hepatitis $B$ as of 2005. The event can be explained by the great effort of the health authorities - in all levels - to come closer to the real scenario, thereby improving prevention and control policies. On the other hand, since then, the rates have decreased, perhaps reflecting the preventive measures, not dismissing the possibility of underreporting.

The western Amazon region of Brazil is the one with the greatest concentration of Hepatitis $B$ cases, being intrafamilial transmission more prevalent than vertical, due to the fact that most children of HBsAg positive seroconvert to anti - HBs before the first year of age (Lobato et al., 2006). Work Bensabath; Smith (2004) investigated the prevalence of Hepatitis $B$ in several populations of the Amazon Basin and reported prevalence rates ranging from 0.7 to $7.2 \%$, being the highest among indigenous, farmers and miners. Similar results were reported by Braga et al (2001) after conducting studies of seroprevalence in indigenous Amazonian populations, finding a wide range of results, from 0 to $20.3 \%$, being higher on the rivers Purus and Juruá area.

Santos et al. (1995) investigated seven urban communities and 24 indigenous groups in the state of Pará, detecting HBsAg presence rates between 0 and $2.1 \%$ in, significantly lower than among the Amerindians, which reported variation of $0-14,2 \%$. In various locations in the State of Acre, Viana et al. (2005) have found a 3.3\% prevalence of HBsAg and $61.5 \%$ for anti - HBC, confirming that this is an area of great epidemiological importance for $H B V$.

In chronic hepatitis $B$, it is possible to stratify the disease process in three phases: immune tolerance, immune activity and inactive carrier of $\mathrm{HBV}$ (MCMAHON, 2008). The immune tolerance phase occurs almost exclusively in vertical infections in children who have high levels of viral load, usually above 20,000 IU / mL, HBeAg positive, normal transaminases and without significant liver injury. This may continue into adulthood, but most evolve to the immune clearance phase at childhood (LOK; MCMAHON, 2007; McMAHON, 2008).

At the moment that the host's immune system recognizes viral antigens as foreigners, the immune clearance phase initiates in an attempt to eradicate the infection, although the goal is rarely achieved, given the inadequate response undertaken. During this period, there is an increase or fluctuation of enzymes necro inflammatory, aminotransferase aspartate (AST) and alanine aminotransferase (ALT) levels, viral load above $2.000 \mathrm{IU} / \mathrm{ml}$ and a wide range of degrees of inflammatory activity and hepatic fibrosis (McMAHON, 2008).

The immune activity starts with individuals being HBeAg positive. Thereafter, the profile may take three different development paths. In the first one, part of the previously infected individuals become inactive carriers after $\mathrm{HBeAg}$ seroconversion to anti - $\mathrm{HBe}$, with low risk of developing cirrhosis and hepatocellular carcinoma. Others will remain in the immune clearance phase, with the persistence of antigen " $e$ ", transaminase elevation and continuity of hepatocellular injury. In a third scenario, some patients who progressed to the stage of inactive carrier, may present recurrent exacerbations of $\mathrm{HBeAg}$ positive 
state, usually accompanied by inflammatory conditions, or even remaining HBeAg negative and anti-HBe positive, but with fluctuations on liver injury and increased levels of viral replication and transaminase. Hence, both $\mathrm{HBeAg}$ positive and negative individuals, may constitute the immune active phase ( LOK; MCMAHON, 2007; MCMAHON, 2008).

For some authors, the exacerbation phase of hepatitis in those HBeAg negative, after a period as inactive carrier, could define a fourth stage, called reactivation phase (LOK; MCMAHON, 2007; FATTOVICH et al., 2005). However, $H B V$ reactivation is a biological phenomenon characteristic of hepadnavirus, regardless of the presence or not of the " $e$ " antigen; and even in cases of previous diagnosis of hepatitis $B$ resolved, relapsing of infection can be detected when patients are undergoing therapies immunosuppressant (VILLENUVE, 2005; FONSECA, 2007). As it has been demonstrated, the natural history of HBV infection is marked by extremes, complex and not totally understood. It depends upon aspects related to the virus itself and, especially, the host.

\section{MATHERIALS AND METHODS}

In April of 2013, a search of articles published on the subject, between 2000 and 2013, was done in the electronic databases PubMed / MEDLINE and LILACS-BIREME. The keywords used in the search were "hepatitis $B$ " alone and in association with others: 1. "Genetic Polymorphisms of Cytokines" 2. "Epidemiology World" 3. "Chronic" and 4. "Antibodies, Hepatitis B". For analysis purposes, the methodology chosen was an article updating the state of the art, namely: 1. Precise formulation of the question, 2. Protocol development of the systematic review, 3. Identification of relevant primary studies, 4. Selection of studies, 5. Extraction of primary studies, 6. Critical evaluation of studies, 7. Data synthesis, 8. Analyzing the data, and finally, 9. Discussion of the data. 128 articles were found; 46 were selected by obeying pre-established inclusion criterion. During the course of the referred studies, nine other articles were identified, of which 1 was considered relevant and was included in the review to be among the most cited. Thus, 47 articles were included in the analysis. Articles published in Portuguese, Spanish, English, French and Italian were considered, having been excluded studies published in other languages, even with summaries in English. Other inclusion standards were adopted, such as the access to the full text, searching time, the target population (infected HBV) and type of study (without boundary).

Data extraction from the selected articles was performed by one reviewer using a pre-structured guide. The following set of information was collected: authors, where the study was performed, year of publication, study period and data from clinical and laboratory analysis of the participants of the research that led to the articles.
Figure 1. Fluxogram of studies included in the review.

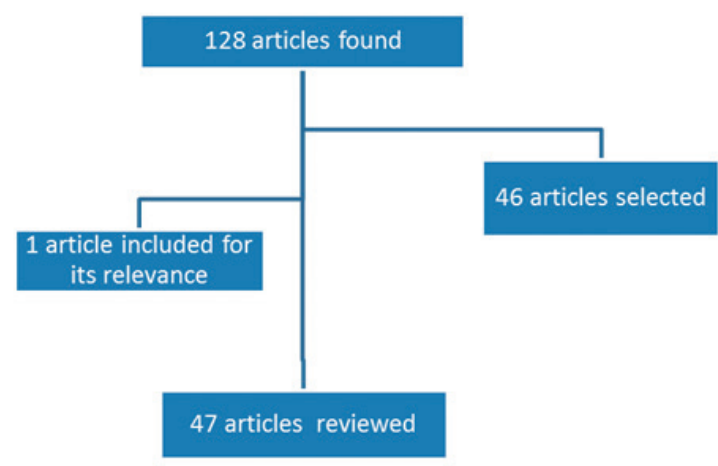

\section{RESULTS AND DISCUSSION}

Currently, an association was found between serum levels of Interleukin 10 (IL10), their combined genotypes and progression of infection by hepatitis $B$ for liver diseases. Zhang and Wang (2006) reported that the mutation of $A$ to $G$ in the region -1082 increases the concentrations of $I L-10$ and ATA combination $(-1082,-819$ and -592) is associated with decreasing of serum levels, and a more benign course of the disease, while GCC (-1082, -819 and -592) is associated with increasing of serum levels and a more progressive pace disease.

In this sense, in a review article, Zhang and Wang (2006) refer to evidence from other studies that the ATCT haplotype $(-1082,-819,-592$ and +117$)$ favors the susceptibility to HBV and evolution to cirrhosis and hepatocellular carcinoma, in addition to increasing serum levels of this cytokine. However, there are differences in the distribution of these polymorphisms. Population with no genotype changes were found in the region -1082 of IL - 10, supported by 138 samples from Chinese patients with hepatocellular carcinoma HBV-infected (WANG et al. , 2006).

Studies indicate that the viral characteristics also influence the pattern of cytokine secretion. Comparing the profile of serum cytokines in patients infected with genotypes $B$ and $C$ of $H B V$, there was an increase in the production of $\mathrm{IL}-10$ in genotype $C$, broadening the Th2 response and favoring a more aggressive course in these cases (YUEN et al., 2007).

In Brazil, the viral genotypes $A$ and $D$ are presented as the most prevalent in most casuistic, being prevalent in the North, Northeast, Midwest and Southeast, and $D$ in the Southern region (MELLO et al., 2007; TONETTO et al., 2009). The importance of genotype F appears in the series of surveys in the Western Amazon (VIANA et al., 2005) or in isolated communities (BERTOLINI et al., 2000).

In chronic hepatitis $B$, even when the immune system fails to control viral replication, there is persistent recruitment of mononuclear cells inflammatory infiltration, chronic inflammation leading to liver damage sustained. Several factors modulate this process, including 
cytokines, such as IL- 6, TNF- $\alpha$ and TGF- 11 (VIERLING, 2007; LARRUBIA et al., 2009). Therefore, the more active viral replication is, the greater is inflammation and the presence of TNF - $\alpha$ at higher levels, which explains the correlation between high serum levels of TNF - $\alpha$ and parenchymal inflammatory activity.

It is known that Th1 and Th2 type responses should be equally balanced for a perfect functioning of the system and for viral clearance, which does not occur in patients with chronicle clinical profiles. (BAUMERT et al., 2007; VIERLING, 2007). The answers to this phenomenon, considering the latest data known, suggest the importance of the interaction of the three factors related to the epidemiology of Hepatitis B: the virus, the host and the environment. Thus, to a profound understanding, the three factors should not be considered separately; failing to have a not compartmentalized view and establishing links between the findings.

The closer you get to reality, the better the prevention, monitoring and therapeutic intervention in patients with hepatitis $B$, declining more and more morbidity and mortality rates, which are still alarming.

There is no doubt that the advent of vaccination contributed to the dramatic decrease in the incidence of cases. However, not everyone has access to basic health services, especially in less developed regions that also present higher endemicity levels. Furthermore, there is a large contingent of chronicity responsible for the reservoir of the disease and the leading staff of cirrhosis and HCC that leads to the death of about 500.000 patients a year.

Advances in all fields of knowledge, including immunology and human genetics, surely will contribute to minimize the problem especially if the approach of a holistic thinking of the human being and their relationship with each other, and with the environment, were taken into consideration. Undoubtedly, future studies with an increased sample and new correlations are needed to ratify the results and contribute to clarification of unresolved issues in immunopathogenesis of chronic HBV infection.

\section{CONCLUSION AND RESEARCH DIRECTION}

The review has shown that there are many ongoing researches, especially in China, with publications referring to the correlation between the clinical presentation of hepatitis B and cytokine polymorphisms, associated with serum levels of the last, but all are inconclusive.

Knowing the genetic polymorphism and serum levels of Th1 and Th2 cytokines in patients with HB acute, self-limited and chronic in individuals vaccinated against Hepatitis $B$, can elucidate the immunological mechanis$m s$ responsible for viral clearance and the chronicity of the infection, as well as providing strategic therapies against the virus to reduce the mortality rates associated with the disease.

\section{REFERENCES}

ALMEIDA, Alessandra M. et al. Revisão sistemática da eficácia do interferon alfa (convencional, peguilado) e lamivudina para o tratamento da hepatite crônica B. Cad. Saúde Pública, v. 25, n. 8, p. 1667-1677, 2009.

ALTER, M.J. Epidemiology and prevention of hepatitis B. Semin. Liver Dis., New York, v. 23, n. 1, 2003, p. 39-46.

BAUMERT, T.F.; THIMME, R.; Von WEIZSÄCKER, F. Pathogenesis of hepatitis B. World J. Gastroenterol., Beijing, v. 13, n. 1, p. 82-90, 2007.

BENSABATH, G.; SOARES, M.C.P. The evolution of knowledge about viral hepatitis in Amazon region: from epidemiology and etiology to the prophilaxys. Rev. Soc. Bras. Med. Trop., Rio de Janeiro, v. 37, p. 14-26, 2004. Supl. 2.

BERTOLETTI, A.; GEHRING, A.J., The immune response during hepatitis B virus infection. J. Gen. Virol., London, v. 87, pt. 6, p. 1439-1449, mar. 2006.

BERTOLINI, D.A. et al. Genotyping of hepatitis B virus in indigenous populations from Amazon region, Brazil. Virus - Reviews \& Research, v. 5, n. 2,2000

BRAGA, W.S.M. et al. Ocorrência da infecção pelo vírus da hepatite B (VHB) e delta (VHD) em sete grupos indígenas do Estado do Amazonas. Rev. Soc. Bras. Med. Trop., Rio de Janeiro, v. 34, n. 4, p. 349-355, 2001.

BRASIL. Ministério da Saúde. Secretaria de Vigilância em Saúde. Hepatite B, 2009. Disponível em: < http://portal.saude.gov.br/portal/saude $>$. Acesso em: 09 jun. 2013.

CHAN, H.L.Y. et al. Associations of cytokine gene polymorphisms and liver fibrosis in chronic hepatitis B. J. Gastroenterol. Hepatol., Melbourne, v. 23, n. 5, p. 783-789, 2008.

CHAN, H.L. et al. High viral load and hepatitis B virus subgenotype ce are associated with increased risk of hepatocellular carcinoma. J. Clin. Oncol., New York, v. 26, n. 2, p. 177-182, 2008.

CHEONG, J.Y. et al. Genetic polymorphism of interferon- $\nu$, interferon- $\gamma$ receptor, and interferon regulatory factor-1 genes in patients with hepatitis B virus infection. Biochem. Genet., New York, v. 44, n. 5/6, p. 246-255, 2006

DEVESA, M.; PUJOL, F.H. Hepatitis B virus genetic diversity in Latin America. Virus Res., Amsterdam, v. 127, n. 2, p. 177-184, 2007.

FATTOVICH, G.; BORTOLOTTI, F.; DONATO, F. Natural history of chronic hepatitis $B$ : special emphasis on disease progression and prognostic factors. J. Hepatol., Copehnagen, v. 48, n. 2, p. 335-352, 2008.

FERRAZ, M.L.G. Testes laboratoriais na investigação de doenças hepáticas. In: MATTOS, A.A; DANTAS-CORRÊA, E.B (Org.). Tratado de Hepatologia. Rio de Janeiro, 2010, p. 21-28.

FONSECA, J.C.F. História natural da hepatite crônica B. Rev. Soc. Bras. Med. Trop., Rio de Janeiro, v. 40, n. 6, p. 672-677, 2007.

GANEM, D.; PRINCE, A.M. Mechanisms of disease: hepatitis B virus infection - natural history and clinical consequences. N. Engl. J. Med., Boston, v. 350, n. 11, p. 1118-1129, 2004.

HADZIYANNIS, S.J.; PAPATHEODORIDIS, G.V. Hepatitis B e antigen-negative chronic Hepatitis B: natural history and treatment. Semin. Liver Dis., v. 26, n. 2 , p. 130-141, 2006.

HUI, C.; LAU, G.K.K. Immune system and hepatitis B virus infection. J. Clin. Virol., Amsterdam, v. 34, supl. 1, p. 44-48, 2005. 
HUSSAIN, B. K; LOK, A. S. F. Hepatitis B virology: acute and chronic Infection - wild-type HBV and HBV Variants. In: GORDON, S. C (Org.). Management of Chronic Viral Hepatitis. New York: Marcel Dekker, Inc, 2001. p. 1-32.

KAO, J.H. et al. Hepatitis B genotypes correlate with clinical outcomes in patients with chronic hepatitis B. Gastroenterology., Baltimore, v. 118 , n. 3, p. 554- 559, 2000.

$\mathrm{KIKI}$, I. et al. Tumor necrosis factor- $\alpha$ levels in hepatitis B virus-related chronic active hepatitis and liver cirrhosis and its relationship to Knodell and Child-Pugh scores. Int. J. Clin. Pract., Esher, v. 60, n. 9, p. 10751079, 2006.

LARRUBIA, J.R. et al. Cytokines - their pathogenic and therapeutic role in chronic viral hepatitis. Rev. Esp. Enferm. Dig., Madrid, v. 101, n. 5, p. 343-51, 2009.

LOBATO, C. et al. Intrafamilial prevalence of hepatitis B virus in Western Brazilian Amazon region:epidemiologic and biomolecular study. J. Gastroenterol. Hepatol., Melbourne, v. 21, n. 5, p. 863-868, 2006.

LOK, A. S. F; MACMAHON, B. J. Chronic Hepatitis B. Hepatology, Baltimore, v. 45, n. 2, p. 507-539, 2007.

LUPBERGER, J.; HILDT, E. Hepatitis B virus-induced oncogenesis. World J. Gastroenterol., Beijing, v. 13, n. 1, p. 74-81, 2007.

MAST, E. E. et al. A comprehensive immunization strategy to eliminate transmission of hepatitis B virus infection in the United States: recommendations of the Advisory Committee on Immunization Practices (ACIP) Part II: immunization of adults. MMWR Recomm. Rep., Atlanta, v. 55, n. 16, p. 1-33, 2006.

McMAHON, B.J. Natural history of chronic hepatitis B - clinical implications. Medscape J. Med., California, v. 10, n. 4, p. 91, 2008.

MELLO, F.C.A. et al. Hepatitis B virus genotypes circulating in Brazil: molecular characterization of genotypes $\mathrm{F}$ isolates. BMC Microbiol., London, v. 7, p. 103, 2007.

PARANÁ, R.; ALMEIDA, D. H.B.V. epidemiology in Latin America. Journal of Clinical Virology, v. 34, supl. 1, p. 130-133, 2005.

PARANÁ, R; VITVITSKI, L.; PEREIRA, J.E. Hepatotropics viruses in brazilian amazon. Braz. J. Infect. Dis., Salvador, v. 12, n. 3, p. 253-256, 2008.

SANTOS, A.K.C.R. et al. A possible correlation between the host genetic background in the epidemiology of hepatitis $B$ virus in the Amazon region of Brazil. Mem. Inst. Oswaldo Cruz, Rio de Janeiro, v. 90, n. 4, p. 435-441, 1995.

SCHOENBORN, J.R.; WILSON, C.B. Regulation of interferon-gamma during innate and adaptive immune responses. Adv. Immunol., New York, v. 96, p. 41-101, 2007.
SIGNH, R. et al. A comparative review of HLA associations with hepatitis $B$ and $C$ infections across global populations. World J. Gastroenterol., Beijing, v. 13, n. 12, p. 1770-1787, 2007.

SILVA, L.C. Aspectos clínicos e diagnósticos das hepatites por vírus e por outras causas. In: SILVA, L.C. Hepatites Agudas e Crônicas. 3 ed. São Paulo: Sarvier, 2003. p. 135-147.

SOUTO, F. J. D. Distribuição da hepatite B no Brasil: atualização do mapa epidemiológico e proposições para seu controle. GED Gastroenterol. Endosc. Dig., São Paulo, v. 18, n. 4, p. 143-150, 1999.

TANG, J.T. et al. T cell immune response is correlated with fibrosis and inflammatory activity in hepatitis B cirrhotics. World J. Gastroenterol., Beijing, v. 12, n. 19, p. 3015-3019, 2006.

THIMME, R. et al. CD8+ T cells mediate viral clearance and disease pathogenesis during acute hepatitis $B$ virus infection. J. Virol., Washington, v. 77, n. 1, p. 68-76, 2003.

TONETTO, P.A. et al. Hepatitis B virus: molecular genotypes and $\mathrm{HBeAg}$ serological status among HBV-infected patients in the southeast of Brazil. BMC Infect. Dis., London, v. 8, n. 9, p. 149, 2009.

VIANA, S. et al. High prevalence of hepatitis B vírus and hepatitis D vírus in the western Brazilian amazon. Am. J. Trop. Med. Hyg., Baltimore, v. 73, n. 4, p. 808-814, 2005.

VIERLING, J.M. The immunology of hepatitis B. Clin. Liver Dis., Philadelphia, v. 11, n. 4, p. 727- 59, 2007.

VILLENEUVE, J.P. The natural history of chronic hepatitis B virus infection. J. Clin. Virol., Amsterdam, v. 34, supl. 1, p. 139-142, 2005.

WANG, J. et al. Interleukin-10 promoter polymorphisms in patients with hepatitis $B$ virus infection or hepatocellular carcinoma in Chinese Han ethnic population. Hepatobiliary Pancreat. Dis. Int., China, v. 5, n. 1, p. 60-64, 2006

WORLD HEALTH ORGANIZATION: WHO, 2007. Progress towards global immunization goals - 2006. Summary presentation of key indicators. Genebra, 2007

YUEN, M.F. et al. Difference in T helper responses during hepatitis flares in hepatitis $B$ e antigen ( $\mathrm{HBeAg}$ )-positive patients with genotypes $B$ and C: implication for early $\mathrm{HBeAg}$ seroconversion. J. Viral Hepat., Oxford, v.14, n. 4, p. 269- 275, 2007.

YOU, J. et al. Peripheral T-Lymphocyte subpopulations in different clinical stagesof chronic HBV Infection Correlate with HBV Load. World J. Gastroenterol., Beijing, v. 15, n. 27, p. 3382-2293, 2009.

ZHANG, L.J.; WANG, X.Z. World J. Gastroenterol., Beijing, v. 12, n. 11, p. 1681-1685, 2006.

Submetido em 13.11.2013;

Aceito em 20.12.2013. 